J. Asiat. Soc. Bangladesh, Sci. 42(1): 21-27, June 2016

\title{
ASSESSMENT OF SOIL QUALITY OF COASTAL SHRIMP CULTURE POND AT CHAKARIA, COX'S BAZAR
}

\author{
M. SHAFIQUL ISLAM*, MAHMODUL HASAN TAREK, \\ MD. SIMUL BHUYAN AND HOSSAIN ZAMAL \\ Institute of Marine Sciences and Fisheries, University of \\ Chittagong, Chittagong, Bangladesh
}

\begin{abstract}
The present study was carried out to find the status of different soil quality variables of coastal shrimp culture pond at different tidal marks of Chakaria, Cox'Bazar during the period from August 2012 to July 2013. The values of different soil quality variables such as sand, silt, clay, $\mathrm{pH}$, organic matter, $\mathrm{NO}_{2}-\mathrm{N}, \mathrm{PO}_{4}-\mathrm{P}$, exchangeable $\mathrm{K}^{+}$, Soil compactness, bulk density, particle density, porosity and Field water capacity fluctuated between $2.04-43.88 \%, 30.80-55.36 \%, 23.98-49.94 \%, 5.9-8.9,1.62-9.95 \%, 4.01-9.92$ $\mu \mathrm{g} / \mathrm{Kg}, 1.14-3.50 \mu \mathrm{g} / \mathrm{Kg}, 0.82-1.74 \mathrm{meq} / 100 \mathrm{~g}, 14.00-31.5 \mathrm{~cm}, 0.80-1.21 \mathrm{gcm}^{-3}, 2.11-2.74$ $\mathrm{gcm}^{-3}, 52.7-65.97 \%$ and $44.27-78.18 \%$ respectively. Significant differences $(\mathrm{p}<0.05)$ in the values of sand, silt, clay, bulk density, porosity, $\mathrm{NO}_{2}-\mathrm{N}$ and field water capacity of soil of the culture ponds at tide marks were observed. Strong correlations between soil bulk density vs sand (0.863), field water capacity vs clay (0.845), field water capacity vs silt $(0.797)$, exchangeable $\mathrm{K}^{+}$vs $\mathrm{PO}_{4}-\mathrm{P}(0.787)$, porosity vs field water capacity $(0.769)$ and porosity vs clay $(0.705)$ were found at $0.01 \%$ level of significance.
\end{abstract}

Key words: Soil quality, Shrimp culture, Tidal marks, Correlation matrix

\section{Introduction}

Soil composed of mineral matter, water, air, organic matter and living community which vary from one area to another at different periods (Mishra 2000). Soil quality controls pond bottom stability, $\mathrm{pH}$, plant nutrients and salinity of water essential for the progression of phytoplankton which are known as the base of food chain of the fish (Hill 1976 and Ekubo and Abowei 2011). Moreover, soil can hold the water providing various nutrients as natural feed for the cultivated shrimp (Boyd 1995 and Soewardi 2002) and serve as a biological sieved through the absorption of the carbon-based remains of food, fish excretions and algal metabolites (Townsend 1982). The excellence of overlying water is strongly affected by pond bottom soil quality (Singh 1982) and is considered as the "chemical laboratory" of the pond (Adams and Evans 1962). Heavier textured soils pose problems of enlargements of deep cracks when dry resulting leakage losses of water (Welch et al. 1977). Sometimes, accumulation and decomposition of the organic matter release organic substances, acids and dissolute minerals harmful for biota (Singh 1982). Due to decomposition of organic matter, soils and sediment become anaerobic inducing

"Corresponding author: Email: shafiqimscu@yahoo.com 
growth of micro-organisms. These micro-organisms produce ammonia, nitrite, ferrous iron, hydrogen sulfide, methane and other reduced compounds (Patrick et al. 1963) which can damage species (Boyd and Musig 1992) because their habitats are closely connected with the sediment. Generally produced ammonia stressed the cultured organisms slowing down feeding activity and growth (Rappaport and Sarig 1975, 1979, Ravch and Avnimelech 1978 and Ram et al. 1981) and mortality (Nix and Ingols 1981). Since Chakaria coastal area under Cox's Bazar district is being extensively used as aquaculture farms by the local community, majority of the farmers involved in aquaculture activities have no adequate knowledge on the soil quality of the ponds of the study area. Therefore the research was carried out to find the soil quality variables of culture ponds.

\section{Materials and Methods}

The study was conducted at Chakaria Upazila (21 ${ }^{\circ} 55^{\prime} 20^{\prime \prime}-21^{\circ} 34^{\prime} 30^{\prime \prime} \mathrm{N}$ and $91^{\circ} 56^{\prime} 20^{\prime \prime}-$ 91 13 '20"E) under Cox's Bazar District in the Division of Chittagong, Bangladesh from August 2012 to July 2013. The selected shrimp culture ponds situated at Chouarfari area under Chakaria Upazila are regularly flooded due to tidal effect.

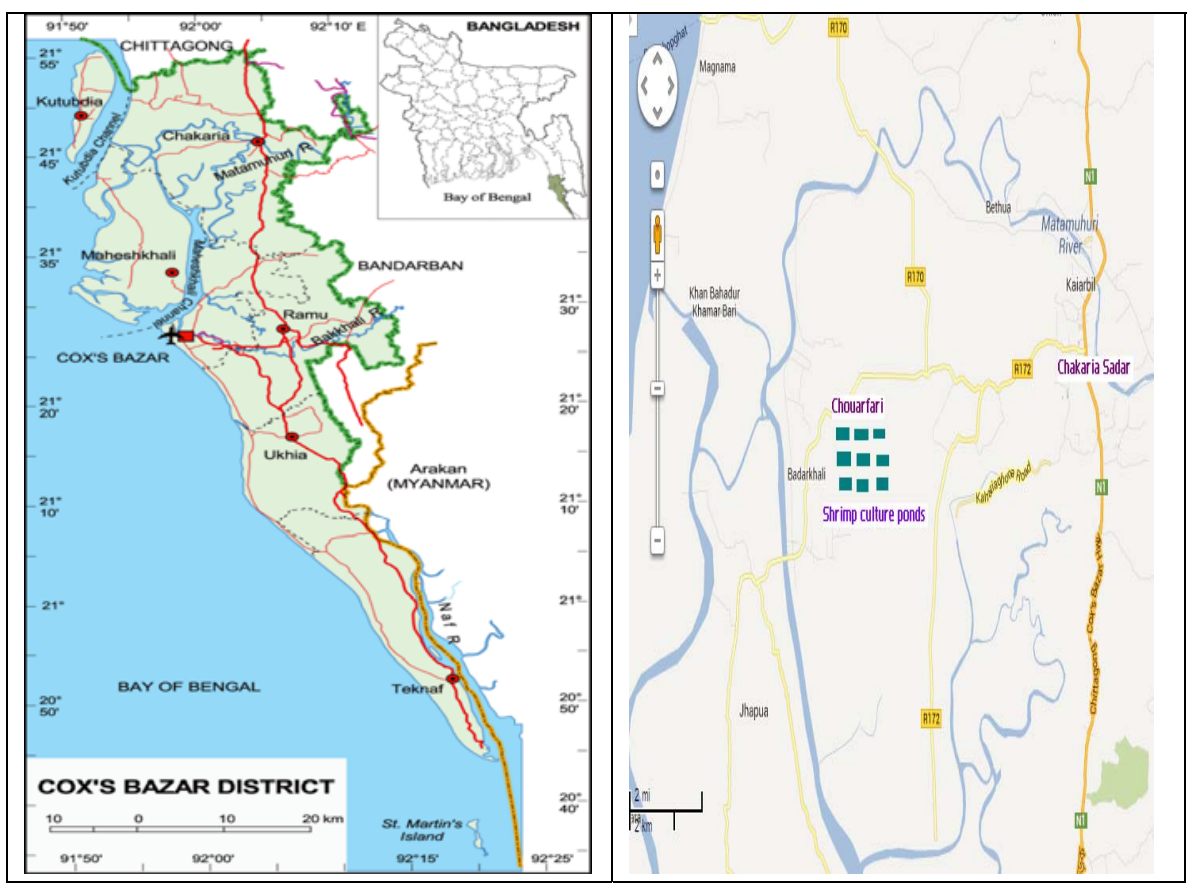

Fig 1. Map of Cox's Bazar District and Chakaria Upazila showing Chouarfari area. 
Soil samples were collected from the study area by using transect method along with stratified random technique (Hale 2013). For soil sampling, three transects maintaining distances of $1 \mathrm{~km}$ were placed at low tide, mid tide and high tide mark. Three culture ponds located in each transect were chosen maintaining an equidistance from one to another for the collection of soil sample. A hand held cylindrical corer (length: $30 \mathrm{~cm}$, diameter: $3.7 \mathrm{~cm}$ ) was used for the collection of three replicated samples from each pond following ' $\mathrm{S}$ ' shaped design.

The collected soil samples were air dried, powdered and passed through a $0.5 \mathrm{~mm}$ mesh sieve. Before analysis, soil samples were finally dried in an oven at $105^{\circ} \mathrm{C}$ for $24 \mathrm{hr}$. Soil $\mathrm{pH}$ and soil compactness were recorded in-situ condition. Soil $\mathrm{pH}$ was determined by soil $\mathrm{pH}$ meter. Other soil variables were analyzed at the Laboratory of Institute of Marine Sciences and Fisheries. The analysis for Exchangeable $\mathrm{K}^{+}$was done at Soil Resource Development Institute (SRDI). Soil organic matter (SOM) was measured by Walkey and Black wet oxidation method modified by Haq and Alam (2005).

Soil texture (\% of sand, silt and clay) in the study area was analyzed by the hydrometer method described by Huq and Alam 2005, modified from Bouyoucos 1936. PhosphatePhosphorus was determined by the method stated by Murphy and Riley (1961). Soil bulk density, field water capacity and soil particle density was determined by the method described by Huq and Alam 2005. Soil compactness was measured by the method described by Jones and Kunz (2004). Exchangeable K+ was determined by the method described by Peterson (2002). Soil sample was also collected by $5.3 \mathrm{~cm}$ long and $1.9 \mathrm{~cm}$ diameter plastic core for bulk density determination (Huq and Alam 2005).

Data analysis: One Way Analysis of Variance (ANOVA) test was performed to find out the significant $(\mathrm{p}<0.05)$ variation among different soil variables measured from different tidal marks in different seasons. A correlation matrix was executed to show the relationship among different soil variables.

\section{Results and Discussion}

The value (average $\pm \mathrm{SD}$ ) of different soil quality variables like texture, soil $\mathrm{pH}$, Exchangeable $\mathrm{K}+, \mathrm{NO}_{2}-\mathrm{N}, \mathrm{PO}_{4}-\mathrm{P}$, Soil organic matter, Bulk density, Particle density, Porosity, Field water capacity, Compactness of shrimp culture ponds situated at different tidal marks are presented in details in Table 1. The percentage of sand fluctuated between 6.17- 41.09 at the pond of different tide marks throughout the study period. The percentage of silt varied between 32.73- 51.47 and percentage of clay ranged between 25.08- 44.65 at the ponds of different tide marks. FAO (1985) reported that the soil of Ellisha Chakaria was mostly Silty Clay loam and Silty Clay. This is completely acquiesced with the mid tide mark and high tide mark soil texture of the present study. 
Table 1 . Soil quality variables of the study area.

\begin{tabular}{|c|c|c|c|c|c|c|}
\hline & \multicolumn{2}{|c|}{ Low Tide Mark } & \multicolumn{2}{|c|}{ Mid Tide Mark } & \multicolumn{2}{|c|}{ High Tide Mark } \\
\hline & Dry season & Wet season & Dry season & Wet season & Dry season & Wet season \\
\hline Parameter & $\begin{array}{l}\text { Average } \\
\pm \mathrm{SD}\end{array}$ & $\begin{array}{c}\text { Average } \\
\pm \mathrm{SD}\end{array}$ & $\begin{array}{l}\text { Average } \\
\pm \mathrm{SD}\end{array}$ & $\begin{array}{l}\text { Average } \\
\pm \mathrm{SD}\end{array}$ & $\begin{array}{c}\text { Average } \\
\pm \mathrm{SD}\end{array}$ & $\begin{array}{l}\text { Average } \\
\pm \mathrm{SD}\end{array}$ \\
\hline Sand (\%) & $41.09 \pm 1.99$ & $38.98 \pm 0.60$ & $14.52 \pm 6.52$ & $14.08 \pm 6.11$ & $6.67 \pm 3.41$ & $6.17 \pm 2.81$ \\
\hline Silt (\%) & $32.73 \pm 1.53$ & $35.93 \pm 1.01$ & $51.47 \pm 1.44$ & $48.39 \pm 2.07$ & $51.26 \pm 4.42$ & $49.19 \pm 5.51$ \\
\hline Clay (\%) & $26.18 \pm 0.70$ & 25.0 & $34.00 \pm 5.87$ & $37.53 \pm 7.00$ & $42.07 \pm 2.48$ & $44.65 \pm 4.26$ \\
\hline Textural Name & \multicolumn{2}{|c|}{ Loam } & \multicolumn{2}{|c|}{ Silty clay loam } & \multicolumn{2}{|c|}{ Silty clay } \\
\hline Soil pH & $7.61 \pm 0.74$ & $6.71 \pm 0.18$ & $8.46 \pm 0.39$ & $6.23 \pm 0.16$ & $8.58 \pm 0.18$ & $6.22 \pm 0.20$ \\
\hline Organic Matter $(\%)$ & $4.81 \pm 1.39$ & $4.84 \pm 1.15$ & $6.59 \pm 1.61$ & $6.51 \pm 1.21$ & $4.99 \pm 1.24$ & $6.32 \pm 1.62$ \\
\hline Organic Carbon (\%) & $2.53 \pm 0.73$ & $2.54 \pm 0.60$ & $3.47 \pm 0.85$ & $3.43 \pm 0.64$ & $2.63 \pm 0.65$ & $3.34 \pm 0.85$ \\
\hline $\mathrm{NO}_{2}-\mathrm{N}(\mu \mathrm{g} / \mathrm{Kg})$ & $7.1 \pm 0.80$ & $9.1 \pm 0.56$ & $6.19 \pm 0.79$ & $7.11 \pm 0.78$ & $5.35 \pm 0.76$ & $6.35 \pm 0.12$ \\
\hline PO4-P $(\mu \mathrm{g} / \mathrm{Kg})$ & $1.71 \pm 0.51$ & $2.74 \pm 0.31$ & $2.26 \pm 0.56$ & $3.11 \pm 0.34$ & $1.38 \pm 0.17$ & $2.62 \pm 0.15$ \\
\hline $\mathrm{K}+(\mathrm{meq} / 100 \mathrm{~g})$ & $0.88 \pm 0.06$ & $1.43 \pm 0.07$ & $1.39 \pm 0.05$ & $1.66 \pm 0.05$ & $1.14 \pm 0.03$ & $1.61 \pm 0.05$ \\
\hline Soil compactness (cm & $21.61 \pm 3.39$ & $19.67 \pm 3.3$ & $21.56 \pm 4.69$ & $21.00 \pm 5.2$ & $25.00 \pm 3.96$ & $23.61 \pm 5.27$ \\
\hline Bulk Density $\left(\mathrm{gcm}^{-3}\right)$ & $1.05 \pm 0.15$ & $0.99 \pm 0.06$ & $0.90 \pm 0.08$ & $0.87 \pm 0.06$ & $0.85 \pm 0.02$ & $0.83 \pm 0.02$ \\
\hline Particle Density $\left(\mathrm{gcm}^{-3}\right)$ & $2.51 \pm 0.17$ & $2.42 \pm 0.14$ & $2.40 \pm 0.17$ & $2.38 \pm 0.18$ & $2.36 \pm 0.04$ & $2.34 \pm 0.04$ \\
\hline Porosity (\%) & $58.50 \pm 5.24$ & $58.99 \pm 1.2$ & $62.29 \pm 5.95$ & $63.10 \pm 5.2$ & $64.01 \pm 0.75$ & $64.33 \pm 0.59$ \\
\hline $\begin{array}{l}\text { Field water capacity } \\
(\%)\end{array}$ & $51.48 \pm 8.18$ & $52.17 \pm 7.8$ & $60.94 \pm 5.91$ & $62.18 \pm 6.2$ & $69.86 \pm 5.88$ & $71.68 \pm 4.88$ \\
\hline $\mathrm{NO}_{2}-\mathrm{N}(\mu \mathrm{g} / \mathrm{Kg})$ & $7.1 \pm 0.80$ & $9.1 \pm 0.56$ & $6.19 \pm 0.79$ & $7.11 \pm 0.78$ & $5.35 \pm 0.76$ & $6.35 \pm 0.12$ \\
\hline
\end{tabular}

The soil $\mathrm{pH}$ fluctuated between 6.22- 8.58 of the ponds of different tidal marks. Pond bottom soil $\mathrm{pH}$ can range from less than 4 to more than 9 but the best $\mathrm{pH}$ for pond soils is considered to be about neutral $\mathrm{pH} 7$ (Boyd 1995). Maximum availability of soil phosphorus usually occurrs at about $\mathrm{pH}$ between 6 and 7.5 (CFA 1995). Most soil microorganisms, and especially soil bacteria, function best at $\mathrm{pH} 7$ to 8 (Boyd 1995). Recommended level of soil $\mathrm{pH}$ for aquaculture is 7.5-8.5. The percentage of soil organic matter fluctuated between 4.81- 6.59 at the ponds of different tide marks (Table 1). The recommended value of organic matter ranged between $4.0-20.0 \%$ suitable for shrimp farming according to feasibility criteria (Poernomo 1992 and Widigdo 2002). In the present study organic matter was found to be within the optimum level. Organic matter was found to increase cation exchange capacity that helped in decomposition of dead algae in pond bottom, consume oxygen and release toxic gas: $\mathrm{CO}_{2}, \mathrm{H}_{2} \mathrm{~S}$, and $\mathrm{NH}_{3}(\mathrm{Colt}$ and Armstrong 1981, Boyd 1995 and Camargo et al. 2005.)

The Nitrite-Nitrogen fluctuated between 5.35 to $9.1 \mu \mathrm{g} / \mathrm{kg}$ at the ponds of different tide marks. According to Townsend (1982), optimum level of nitrite nitrogen is (5-10) $\mu \mathrm{g} / \mathrm{kg}$, which is similar to the nitrite-nitrogen of the present study. The Phosphate-Phosphorus varied between 1.38 to $3.11 \mu \mathrm{g} / \mathrm{kg}$ at the ponds of different tide marks. Optimum level of phosphate-phosphorus is $(0.50-1.50) \mu \mathrm{g} / \mathrm{kg}$ suitable for aquaculture (Townsend 1982). In the present study, amount of phosphate-phosphorus was found to be above the optimum 
level, which might be due to the deposition of phosphate into the soil which comes with tidal water. The exchangeable $\mathrm{K}+$ fluctuated between 0.88 to $1.66 \mathrm{meq} / 100 \mathrm{~g}$ at the ponds of different tide marks (Table 1). Exchangeable $\mathrm{K}+$ at the range of (0.6-1.0) $\mathrm{meq} / 100 \mathrm{~g}$ is high and greater than $1.0 \mathrm{meq} / 100 \mathrm{~g}$. The Soil compactness fluctuated between $19.67 \mathrm{~cm}$ to $25 \mathrm{~cm}$ at the ponds of different tide marks. According to Municipality of central Saanich Resource Atlas, a clay layer at $20-50 \mathrm{~cm}$ depth will restrict rooting, sub soiling at silty clay loam soil, which represents the compactness and it is similar to the present study. The percentage of soil bulk density fluctuated between 0.83 to $1.05 \mathrm{~g} \mathrm{~cm}^{-3}$ at the ponds of different tide marks. Bulk density of a mineral soil is normally between 1.0 and $1.6 \mathrm{~g} / \mathrm{cm}^{3}$. Townsend (1982) reported that soils rich in organics and some friable clay may have a bulk density well below $1 \mathrm{~g} / \mathrm{cm}^{3}$ and this result is similar to the present study. The Soil particle density fluctuated between 2.34 to $2.51 \mathrm{~g} \mathrm{~cm}^{-3}$ at the ponds of different tide marks. According to Townsend 1982, the particle density of most mineral soil is in the range of 2.60 to $2.75 \mathrm{~g} \mathrm{~cm}^{-3}$, which strongly supports particle density of the present study. The soil porosity ranged between 58.50 to $64.33 \%$ at these ponds. Total porosity values for unconsolidated materials lie in the range of $25 \%-70 \%$. Porosity of silt is $35-50 \%$ and porosity of clay is $40-70 \%$ (Freeze and Cherry 1979). In the present study the porosity of soil is also in the range of $25-70 \%$. The percentage of field water capacity varied between 51.48- 71.68 at these ponds. According to NRCCA (2010), the volumetric soil moisture content residual at field capacity is about 15 to $25 \%$ for sandy soils, 35 to $45 \%$ for loam soils, and 45 to $65 \%$ for silty clay loam soils and it can be more for silty clay and clay type soil. In the present study field capacity at mid tide mark and low tide mark are within the range of NRCCA (2010).

The interrelationship among soil variables found in the present study was measured at different significant levels. Significant positive correlations between soil bulk density vs sand (0.863), field water capacity vs clay $(0.845)$, field water capacity vs silt $(0.797), \mathrm{K}+$ vs $\mathrm{PO}_{4}-\mathrm{P}(0.787)$, porosity vs field water capacity $(0.769)$ and porosity vs clay $(0.705)$ were observed at $1 \%$ level of significance. These results are similar to the results stated by NRCCA (2010). Moderate positive correlations were found between silt vs clay $(0.541)$, silt vs porosity $(0.542)$, organic matter vs silt $(0.452)$, organic carbon vs silt (0.454). These results are similar to the results found by NRCCA (2010). Strong negative correlations were observed between field water capacity vs sand (-0.931), sand vs clay ($0.878)$, sand vs silt $(-0.874)$, sand vs porosity $(-0.698)$, silt vs bulk density $(-0.741)$, clay vs bulk density (-0.792), bulk density vs porosity $(-0.854)$, field water capacity vs bulk density $(-0.821)$ at the level $\mathrm{p}<0.05$. Rasool et al (2014) found the similar result between bulk density vs porosity. 
Healthy and maximum growth of culture species in the coastal aquaculture pond depend mainly on the optimum level of sediment and water quality variables. Therefore the present result may help the local community for choosing a suitable culture pond for enhancing their aquaculture production in the Chouarfari area of Chakaria, Cox's Bazar.

\section{References}

Adams, F. and C. E. Evans.1962. A rapid method of measuring lime requirement of Red - yellow Podzolic soils. Soil Science Society of America, Proceedings. 26: 355 - 357.

Avnimelech, Y. 1984. Reactions in fish pond sediments as inferred from sediment cores data. Publication No. 341, Technion Israel Institute of Technology, Soils and Fertilizers Research Center, Haifa, Israel, pp. 1-46.

Bendschneider, K. and R. J. Robinson. 1952. A new spectrophotometric method for the determination of nitrite in seawater. J. Mar. Res. 11: 87-96. BIENFANG, P. K. 1975.

Boyd, C. E. 1995. Bottom Soils, Sediment, and Pond Aquaculture. Chapman and Hall, New York, New York, 348 pp.

Boyd, C. E. and Y. Musig. 1992. Shrimp pond effluents: Observations of the nature of the problem on commercial farms. Proceeding of the special session on shrimp farming. Edited by J. Wyban. World aquaculture society, Baton rouge, LA. USA 195-197.

Bouyoucos, G. J. 1936. Directions for Making Mechanical Analysis of Soils by the Hydrometer Method. Soil Sci. 42: 3.

California Fertilizer Association (CFA). 1995. Western Fertilizer Handbook. $8^{\text {th }}$ ed. California Fertilizer Association. Interstate Publishers, Inc. Danville, Illinois. 338p.

Camargo, J. A., A. Alonso and A. Salamanca. 2005. Nitrate toxicity to aquatic animals: a review with new data for freshwater invertebrates. Chemosphere. 58: 1255-1267. http://dx.doi.org/10.1016/j.chemosphere.2004.10.044

Colt, J. E. and D. A. Armstrong. 1981. Nitrogen toxicity to crustaceans, fish, and molluscs. In: L.J. Allen and E.C. Kinney (eds.), Proceedings of the Bio-engineering Symposium for Fish Culture. American Fisheries Society, Bethesda, MD. pp. 34-37.

Ekubo, A. A. and J. F. N. Abowei. 2011. Review of Some Water Quality Management Principles in Culture Fisheries. Research Journal of Applied Sciences, Engineering Technology, 3: 1342-1357. Retrieved from http://maxwellsci.com/.

Farmer, A. 1989. Proposed research programme for the brackishwater station to be established at Paikgacha. Final Report submitted to World Bank second agricultural research project, Fisheries Research Institute, GoB. Available online at: http://www.fao.org/docrep/field/ 003/AC370E/AC370E21. htm\#ch1.2.2, date accessed: 12 July 2009.

FAO, 1985. A report on Tidal area study. Fisheries resources survey system. FAO/UNDP-BGD /79/015. 407p.

Freeze, R. A. and J. A. Cherry. 1979. Groundwater. Prentice-Hall, Inc., Englewood Cliffs. 604p.

Hale, C. 2013. Earthworms of the Great Lakes. Kollath-Stensaas Publishers. 47p.

Huq, S. M. I. and M. D. Alam. 2005. A hand book on analysis of soil, plant and water, 246 p.

Hill, A. R. 1976. The environmental impacts of agricultural land drainage. J. Environ. Mgmt., 4: 251-274.

Jones, D. and M. Kunz. 2004. Guide to sampling soil compaction using hand-held soil penetrometers; Center for Environmental Management of Military Lands (CEMML), Colorado State University: Fort Collins, CO, USA. 10p. 
Mishra, M. 2000. Harvesting practices and management of two critically endangered medicinal plants in the natural forests of central India. Proceedings in the International seminar on "harvesting of non-wood forest products", Held at Menemen-Izmir (Turkey), 2-8 October 2000. pp. 335-341.

Murphy, J. and J. P. Riley. 1962. A modified single solution method for the determination of phosphate in natural waters. Anal. Chim. Acta. 27: 31-36.

Nix, J. and R. Ingols. 1981. Oxidized manganese from hypolimnetic water as a possible cause of trout mortality in Hatcheries. Prog. Fish-Cult. 43: 32-36.

Northeast Region Certified Crop Adviser (NRCCA) Study Resources, 2010. Soil and water management. 74p.

Patrick, Z. A., T. A. Toussoun and W.C. Snyder. 1963. Phytotoxicity substance in arable soils associated with decomposition of plant residues. Phytopathology. 53: 152-161

Peterson, L. 2002. Analytical Methods of Soil, Water, Plant Material Fertilizer. Soil Research Division Institute. pp. 21-24.

Poernomo, A. 1992. Pemilihan lokasi tambak udang berwawasan lingkungan. Pusat Penelitiandan Pengembangan Perikanan, Jakarta. PHP/KANPATEK/004/1992.1-10p.

Ram, N., S. Ulizur and Y. Avnimelech. 1981. Microbial and chemical changes occurring at the mud-water interfacein an experimental fish aquarium. Bamidgeh, Isr. J. Aquac. 33: 7185.

Rappaport A. and S. Sarig. 1975. Results of tests in intensive growth of fish at the Genosarstation ponds in 1974. Bamidgeh. 27:75-92.

Rappaport V. and S. Sarig. 1979. The effect of population density of carp in monoculture under conditions of inten- sive growth. Bamidgeh. 31: 26-34.

Rasool S. N., S.W. Gaikwad and M.A. Talat. 2014. Relationships between soil properties and slope Segments of sallarwullarhama watershed in the Liddar catchment of Jammu and Kashmir, Asian Journal of Engineering Research. 2: 1-10.

Raveh, A. and Y. Avnimelech. 1978. The effect of drying on the colloidal properties and stability of humic compounds. Plant Soil. 50:545-552.

Rimon, A. and M. Shilo. 1982. Factors which affect the intensification of fish-breeding in Israel. 1. Physical, chemical and biological characteristics of the intensive fish ponds in Israel. Bamidgeh. 34: 87-100.

Singh, V.P. 1982, Management of acid sulfate soils for brackishwater fishponds: experience in the Philippines. Publ. Inst. Land Reclam. Improv. Wageningen. 31: 354-66.

Soewardi, K. 2002. Pengelolaankualitas air tambak. Makalahdalam seminar penetapanstandarkualitas air buangantambak. DitjenPerikananBudidaya, pp.7-9.

Townsend, W. N. 1982. An Introduction to the Scientific Study of the Soil. Edward Amold (Publishers) Ltd. U.K, 209p.

Welch, H. E., P. E. K. Symons and D. W. Narver. 1977. Some effects of potato farming and forest clear-cutting on small New Brunswick streams. Fisheries and Marine Service Technical Report. 745. $12 \mathrm{p}$

Widigdo, B. 2002. Perkembangandanperananperikananbudidayadalampembangunan. Makalahdalam seminar penetapanstandarkualitas air buangantambak, Ditjen Perikanan Budidaya, Puncak 7 - 9 Agustus 2002. 12p. 